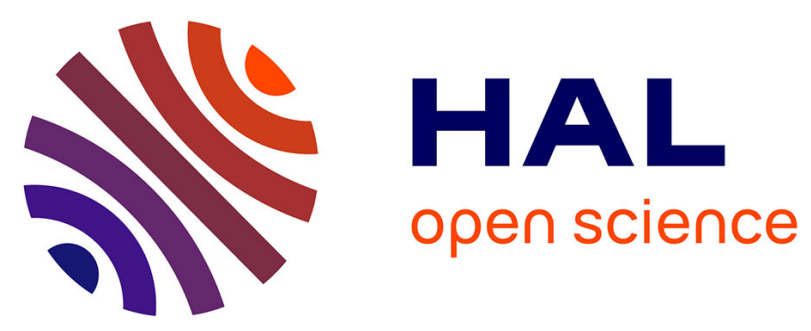

\title{
Interactions between invasive ctenophores in the Black Sea: assessment of control mechanisms based on long-term observations
}

Tamara A. Shiganova, Louis Legendre, Alexander S. Kazmin, Paul Nival

\section{- To cite this version:}

Tamara A. Shiganova, Louis Legendre, Alexander S. Kazmin, Paul Nival. Interactions between invasive ctenophores in the Black Sea: assessment of control mechanisms based on long-term observations. Marine Ecology Progress Series, 2014, 507, pp.111-123. 10.3354/meps10806 . hal-03502768

\section{HAL Id: hal-03502768 \\ https://hal.science/hal-03502768}

Submitted on 26 Dec 2021

HAL is a multi-disciplinary open access archive for the deposit and dissemination of scientific research documents, whether they are published or not. The documents may come from teaching and research institutions in France or abroad, or from public or private research centers.
L'archive ouverte pluridisciplinaire HAL, est destinée au dépôt et à la diffusion de documents scientifiques de niveau recherche, publiés ou non, émanant des établissements d'enseignement et de recherche français ou étrangers, des laboratoires publics ou privés.

\section{(c)(1)}

Distributed under a Creative Commons Attribution| 4.0 International License 


\title{
Interactions between invasive ctenophores in the Black Sea: assessment of control mechanisms based on long-term observations
}

\author{
Tamara A. Shiganova ${ }^{1, *}$, Louis Legendre ${ }^{2,3}$, Alexander S. Kazmin ${ }^{1}$, Paul Nival ${ }^{2,3}$ \\ ${ }^{1}$ P. P. Shirshov Institute of Oceanology, Russian Academy of Sciences, Nakhimovsky Prospekt 36, Moscow, Russia \\ ${ }^{2}$ Sorbonne Universités, UPMC Univ Paris 06, UMR 7093, LOV, Observatoire Océanologique, 06230 Villefranche-sur-Mer, France \\ ${ }^{3}$ Centre National de la Recherche Scientifique (CNRS), UMR 7093, LOV, Observatoire Océanologique, \\ 06230 Villefranche-sur-Mer, France
}

\begin{abstract}
Invasion of the carnivorous ctenophore Mnemiopsis leidyi in the Black Sea in the 1980s disrupted the ecosystem, which started to recover with the arrival of the predatory ctenophore Beroe ovata in 1997. We used the results of $25 \mathrm{yr}$ of field observations and experiments in the northeastern Black Sea to assess 3 hypotheses that should explain most of the population dynamics of $M$. leidyi and B. ovata. The first hypothesis is that since its arrival, B. ovata has controlled the period of the year during which $M$. leidyi was present in sizable concentrations. This hypothesis is supported by the observation that $M$. leidyi abundance was sizable almost yearround (spring, summer, autumn) before the arrival of $B$. ovata but was sizable only for a period of 1.3 to $3.1 \mathrm{mo}$ (mostly summer) after its arrival. The second hypothesis is that the same sequence of predator-prey mechanisms that led B. ovata to shorten the duration of a sizable $M$. leidyi population occurred every year irrespective of interannual environmental variability. This is supported by the repetition of the same reproductive sequences of the 2 ctenophores yearly since 1999 despite differences in environmental factors. The third hypothesis (i.e. environmental conditions influenced the joint abundances of the 2 species) is supported by the observed covariability between the 2 species every year. Experimental and field results identified temperature, food and wind as the key factors influencing $M$. leidyi, which suggested that the interannual environmental variations that affect $M$. leidyi abundance cause proportional changes in $B$. ovata abundance. Some aspects of these hypotheses have been previously examined in the literature, but this is the first study in which they are assessed using a consistent set of data.
\end{abstract}

KEY WORDS: Ctenophores $\cdot$ Invasion $\cdot$ Black Sea $\cdot$ Mnemiopsis leidyi $\cdot$ Beroe ovata $\cdot$ Population dynamics $\cdot$ Long-term data

Resale or republication not permitted without written consent of the publisher

\section{INTRODUCTION}

The Black Sea is semi-enclosed, non-tidal and meromictic (i.e. permanently stratified by a pycnohalocline), with relatively low salinity (12 to 22 ) and a thin (60 to $200 \mathrm{~m}$ ) oxygenated surface layer overlying waters dominated by hydrogen sulfide. The thinness of the oxygenated layer, in which the aerobic ecosystem of the Black Sea is concentrated, makes this ecosystem vulnerable to environmental changes.
From the 1970s, anthropogenic effects turned the Black Sea into one of the most polluted and mismanaged water bodies worldwide. The proximate causes of severe environmental and ecosystem degradation included the regulation of major rivers; increased riverine inflows of phosphate, nitrate and organic matter resulting from the heavy use of fertilizers for agriculture, which led to increased phytoplankton growth including blooms of harmful species (primary production doubled over the entire sea and increased 
by 1 order of magnitude in the northwest); eutrophication-related outbursts of the native gelatinous scyphomedusa Aurelia aurita (Linnaeus, 1758); blooms of the dinoflagellate Noctiluca scintillans (Macartney) Kofoid \& Swezy 1921; overfishing of predator fish and dolphins; intensification of shipping; introduction of non-native species; and climatic variations (Ivanov \& Beverton 1985, Caddy \& Griffiths 1990, Zaitsev \& Alexandrov 1998).

Because of environmental disturbances and increasing propagule pressure of invasive species from different sources in the early 1980s, many non-native species became established in the Black Sea, the most harmful being the carnivorous ctenophore Mnemiopsis leidyi A. Agassiz, 1865 (Vinogradov et al. 1989). This species was transported to the Black Sea in ballast waters of ships from Tampa Bay in the Gulf of Mexico (Reusch et al. 2010, Ghabooli et al. 2011), spread around the sea, and reached high abundances that caused cascading effects on most components of the ecosystem. Bottom-up effects included collapsing planktivorous fish populations and the disappearance of large pelagic fish and dolphins. Top-down effects included decreased zooplankton diversity and stocks (maximum annual zooplankton biomass declined to ca. $0.5 \mathrm{mg} \mathrm{C} \mathrm{m}^{-3}$, which was almost 2 orders of magnitude lower than during the previous period); increased phytoplankton biomass because of decreased grazing pressure from zooplankton; increased bacterioplankton, favoured by the higher production of phytoplankton exudates; and increased heterotrophic flagellates and ciliates, which fed on the increasing bacteria. By the late 1980s, the pelagic ecosystem had become dominated by gelatinous plankton (Shiganova et al. 2004). From the Black Sea, M. leidyi expanded into the Sea of Azov, the Sea of Marmara, and the eastern and western Mediterranean Sea and was introduced into the Caspian Sea in ballast waters from the Black Sea (Shiganova et al. 2001b).

The sizes of $M$. leidyi populations were not controlled by predators until 1997. In that year, another carnivorous ctenophore, Beroe ovata sensu Mayer (Bayha et al. 2004), arrived in the Black Sea in ballast waters from North American coastal areas (Konsulov \& Kamburska 1998, Seravin et al. 2002). B. ovata is a predator of zooplanktivorous ctenophores, mostly $M$. leidyi and Bolinopsis vitrea in North American waters (Bayha et al. 2004). In the upper layer of the Black Sea, B. ovata only feeds on $M$. leidyi, although it could also feed on the ctenophore Pleurobrachia pileus (O. F. Muller, 1776), which generally lives in deeper waters offshore (Shiganova et al. 2001a). After the arrival of B. ovata, the Black Sea ecosystem began to recover progressively (Finenko et al. 2003, Shiganova et al. 2004). An additional factor that favoured the recovery of the ecosystem was a decrease in eutrophication, which resulted from reduced anthropogenic nutrient inputs (Cociasu et al. 2008). This was accompanied by a decrease in total phytoplankton biomass, with harmful algae blooms becoming rarer and less intense. The combination of these factors in the late 1990s led to a general improvement of the Black Sea ecosystem (Oguz \& Velikova 2010).

Different studies have assessed changes in the environmental status of the Black Sea ecosystem from various perspectives, such as increasing eutrophication from nutrient enrichment and its effect on biodiversity (Petranu 1997, Zaitsev \& Alexandrov 1998), fish stock collapses (Daskalov et al. 2007, Llope et al. 2011), impacts of climate change on ecosystem functioning (Oguz \& Cokacar 2003), and impacts of $M$. leidyi on all trophic levels and fish stocks (Shiganova 1998, Shiganova et al. 2004, Oguz et al. 2008). The interannual variability in $M$. leidyi was ascribed to changes in surface water temperature and food concentration, i.e. edible micro- and mesozooplankton (Shiganova et al. 2001b). However, no study to date has investigated the mechanism by which the populations of $M$. leidyi are controlled by $B$. ovata. Understanding these mechanisms in the Black Sea is especially important because M. leidyi distributions are rapidly expanding in waters around Europe (e.g. Faasse \& Bayha 2006, Javidpour et al. 2006, Boero et al. 2009, Galil et al. 2009, Shiganova \& Malej 2009, Fuentes et al. 2010) and have been recorded in the Indian Ocean and Australian waters (Costello et al. 2012).

In this paper, we assess 3 hypotheses using a unique set of field observations and experimental data from the northeastern Black Sea over $>25 \mathrm{yr}$. The first hypothesis is that every year since the arrival of B. ovata in the Black Sea, its population dynamics have controlled the period of the year during which $M$. leidyi was present in sizable concentrations. However, B. ovata and M. leidyi continued to coexist year-round, the latter in small numbers in winter until the spring increase in water temperature, after which it occurred, some years, in high reproductive populations until the seasonal development of B. ovata in summer. Because of this, and if the first hypothesis holds, the second hypothesis is that every year, the same sequence of predator-prey mechanisms led $B$. ovata to shorten the duration of sizable $M$. leidyi populations relative to the situation before the arrival of the predator, irrespective of 


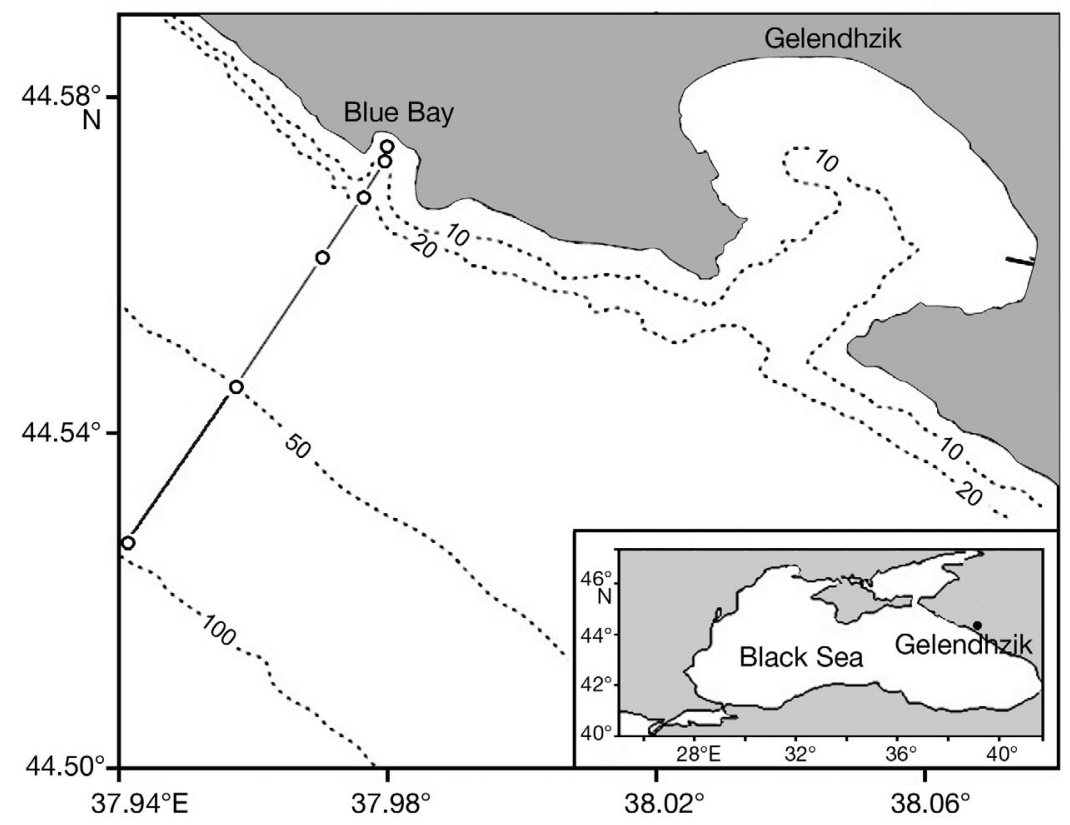

Fig. 1. Study area in the northeastern Black Sea, showing the location of the sampling transect from Blue Bay to $100 \mathrm{~m}$ depth. Inset: Black Sea

with a free exchange of water with the open sea and the offshore area (Fig. 1). In the studied area of the Black Sea, temperature varied from $6^{\circ} \mathrm{C}$ in winter to $30^{\circ} \mathrm{C}$ in summer, and salinity varied from 17 to 18 . Meandering of the Rim Current (cyclonic contour current on the continental slope of the Black Sea) frontal zone generates eddies, mainly anticyclonic, which migrate offshore and exchange water and plankton between coastal and offshore areas. In addition, wind-driven Ekman transport affects the numerical abundance and biomass of plankton in the coastal zone (Zatsepin et al. 2010).

\section{Data collection}

Most of the data on mesozooplankton and gelatinous species were col-

interannual environmental variability. Finally, because there were strong interannual variations in abundances of both $M$. leidyi and B. ovata, the third hypothesis is that environmental conditions influenced the joint abundances of the 2 species.

\section{MATERIALS AND METHODS}

\section{Study area}

Samples were collected in the northeastern Black Sea. The sampling area included Blue Bay, which is a small, semi-enclosed body of water, 7 to $14 \mathrm{~m}$ deep, lected during expeditions of the P. P. Shirshov Institute of Oceanology, Russian Academy of Sciences, from 1992 to 2011. Temperature, salinity and plankton observations used in the present study were made at a monitoring station in Blue Bay and along a transect from Blue Bay to offshore (Fig. 1, Table 1). We also used some data from 1988 to 1992 (Vinogradov et al. 1992).

Temperature and salinity were recorded vertically with a SeaBird CTD probe. Zooplankton (including ovae and larvae of ctenophores) were collected with a Juday plankton net $\left(0.1 \mathrm{~m}^{2}\right.$ opening, $180 \mu \mathrm{m}$ mesh size), and gelatinous taxa (ctenophores and medusae) were collected with a Bogorov-Rass net $\left(1 \mathrm{~m}^{2}\right.$

Table 1. Sampling areas, years and frequencies in the northeastern Black Sea (Fig. 1). Reference lines cited in the figure legends

\begin{tabular}{|c|c|c|c|}
\hline Sampling area & Years & Frequency & $\begin{array}{l}\text { Reference } \\
\text { line }\end{array}$ \\
\hline Blue Bay monitoring station ( $7 \mathrm{~m}$ depth) & 1991-1996 & Monthly (Khoroshilov \& Lukasheva 1999) & 1 \\
\hline Blue Bay monitoring station ( 7 m depth) & 2000-2011 & $\begin{array}{l}\text { Every day March-November, every } 10 \mathrm{~d} \\
\text { December-March }\end{array}$ & 2 \\
\hline $\begin{array}{l}\text { Transect from Blue Bay to a depth of } \\
500 \text { or } 1000 \mathrm{~m} \text { offshore } \mathrm{a}^{\mathrm{a}}\end{array}$ & 1992-1999 & $\begin{array}{l}\text { Twice a year in spring and summer, during } \\
\text { surveys in the whole northeastern Black Sea }\end{array}$ & 3 \\
\hline $\begin{array}{l}\text { Transect from the Blue Bay monitoring station } \\
\text { to a depth of } 100 \text { or } 500 \mathrm{~m} \text { offshore } \mathrm{a}^{\mathrm{a}}\end{array}$ & 2000-2011 & $\begin{array}{l}\text { Once or twice a month from March } \\
\text { to the end of November or December }\end{array}$ & 4 \\
\hline $\begin{array}{l}\text { Whole northeastern Black Sea } \\
\text { (including transect) }\end{array}$ & 1992-1999 & Twice a year (spring and summer) & 5 \\
\hline
\end{tabular}


opening, $500 \mu \mathrm{m}$ mesh size) or a smaller version of it $\left(0.2 \mathrm{~m}^{2}\right.$ opening, $500 \mu \mathrm{m}$ mesh size). All samples were collected using vertical hauls from bottom to surface. The anoxic layer was not present at any of the sampling stations.

The ctenophores obtained from the vertical net hauls were immediately separated from other organisms using a $2 \mathrm{~mm}$ mesh sieve. All ctenophores including the smallest larvae and the ovae were measured alive immediately after collection, by size groups. We measured the total length of Mnemiopsis leidyi, i.e. with lobes. Small organisms of both M. leidyi and Beroe ovata were counted and measured under a binocular microscope (Shiganova et al. 2001a). For $M$. leidyi, the size groups were $<2,3-5$, $6-10,11-20,21-30,31-40,41-50$, and $>50 \mathrm{~mm}$. The life stages of Black Sea M. leidyi were defined as follows: <2 mm, hatched larvae; 3-5 mm, larvae; 6-10 mm, cydippid larvae; $11-20 \mathrm{~mm}$, transition from cydippid to lobate juveniles; 21-30 mm, lobate juveniles; 31-40 mm, beginning of maturity and reproduction, accepted as adults; and $>40 \mathrm{~mm}$, adults. For $B$. ovata, the size groups were $<4,4-8,9-30,31-40$, 41-50, and $>50 \mathrm{~mm}$. In the Black Sea under favourable conditions, $B$. ovata can reach maturity and start reproduction at a length of $40 \mathrm{~mm}$. Its life stages are as follows: $<8 \mathrm{~mm}$, larvae; $8-40 \mathrm{~mm}$, juveniles; and $>40 \mathrm{~mm}$, adults. The smallest larvae and ovae were also counted and measured alive from the zooplankton samples and then preserved in $2 \%$ formaldehyde.

The total numbers of individuals of $M$. leidyi and $B$. ovata were used to estimate their total abundances. The biomass of individual ctenophores was estimated as both biovolume $(\mathrm{ml}$, displacement volume method) and wet weight (mg or g). Biovolumes and wet weights provided equivalent results for the 2 ctenophores. Using these measurements, Shiganova et al. (2001a) obtained the following regression equation for M. leidyi: $\mathrm{W}=0.043 \mathrm{~L}^{1.896}(\mathrm{r}=0.94, \mathrm{p}<0.01$, $\mathrm{n}=300)$, where $\mathrm{W}$ is the wet weight $(\mathrm{g})$, and $\mathrm{L}$ is the total length with lobes $(\mathrm{mm})$. Similarly, Shiganova et al. (2004) obtained the following equation for $B$. ovata: $\mathrm{W}=0.0062 \mathrm{~L}^{1.9227}(\mathrm{r}=0.85 \mathrm{p}<0.01, \mathrm{n}=250)$.

\section{Wind data processing}

To investigate the possible effect of wind on the observed concentrations of $M$. leidyi in the sampled inshore area, we computed the velocity of the wind favouring Ekman transport normal to the coastline direction. The monthly mean zonal $(U)$ and merid- ional $(V)$ components of the surface wind, spatially averaged for an area of $1^{\circ}$ latitude $\times 1^{\circ}$ longitude centred over the measurements site, were obtained from the U.S. National Centers for Environmental Prediction/National Center for Atmospheric Research (NCEP/NCAR) Reanalysis Project archive (http:// nomad3.ncep.noaa.gov/ncep_data, Reanalysis-2 nonpressure level). In the Northern Hemisphere, Ekman transport is directed to the right relative to the surface wind vector (e.g. Gill 1982). In the case of a strictly zonally oriented coast, westerlies would favour an offshore flow, and easterlies would produce transport toward the coast. In such a situation, the variability of the zonal wind component would be enough to explain the variability of the Ekman transport normal to the coastline. However, in our specific location, the coastline is tilted by approximately $20^{\circ}$ clockwise relative to the parallel of latitude, and consequently the projection of the meridional wind component to the coastline is not equal to zero, i.e. the meridional component also contributes to the Ekman flow normal to the coastline. Adequate estimation of transport normal to the coastline in this situation is provided by wind velocity parallel to the coastline. Using vector algebra, we calculated the magnitude of the wind velocity parallel to the coastline $(W)$ from the $U$ and $V$ wind components as $W=U \times \cos 20^{\circ}-V \times \sin 20^{\circ}$. For convenience, the $W$ values were marked as positive for the coast transport-favourable winds and negative for the offshore transport-favourable winds.

\section{Statistical analyses}

Data were entered into MS Word Excel spreadsheets, which were used to compute basic statistics (e.g. linear regressions) and draft figures. MannWhitney $U$-tests were performed with Leon Avery's program (http://elegans.som.vcu.edu/ leon/stats/ utest.html), and $\chi^{2}$ probabilities were calculated with John Walker's program (www.fourmilab.ch/rpkp/ experiments/analysis/chiCalc.html).

\section{RESULTS}

\section{Seasonal and interannual variability of Mnemiopsis leidyi and Beroe ovata}

With the arrival of Beroe ovata in the Black Sea in 1997 (in 1999 in the northeastern area considered here, which includes Blue Bay), the period of the year during which Mnemiopsis leidyi was present 
changed drastically; until 1998 (no surveys were conducted in autumn 1997, spring 1998 and autumn 1998), M. leidyi occurred in sizable (sometimes very large) concentrations during spring, summer and autumn, and from 1999, it occurred in sizable concentrations (i.e. $\geq 5$ ind $\mathrm{m}^{-3}$ ) only during summer, such concentrations ending with the initiation of the seasonal development of $B$. ovata (Fig. 2). In the springs of 2006 and 2009, values were slightly higher than in other springs after 1999 but still much lower than the corresponding summer values. We compared the statistical distributions of $M$. leidyi before and after the arrival of $B$. ovata in the 3 sampling seasons (Mann-Whitney $U$-tests). In summer, M. leidyi abundances before (B) and after (A) the arrival of $B$. ovata belonged to the same statistical population $(U=$ 82.5, 2-tailed $\mathrm{p}=0.284, \mathrm{n}_{\mathrm{B}}=10, \mathrm{n}_{\mathrm{A}}=13$ ), whereas in spring and autumn, $M$. leidyi abundances before the arrival of $B$. ovata were larger than those after $(U=$ 99.0 and 52.0, respectively, with corresponding 1tailed $\mathrm{p}<0.001$ and $<0.001, \mathrm{n}_{\mathrm{B}}=9$ and $4, \mathrm{n}_{\mathrm{A}}=12$ and 13 , respectively). The few values available for winter show a trend similar to the trends observed in spring and autumn, i.e. much lower abundances after 1999 ( 0.1 to 0.2 ind. $\mathrm{m}^{-3}$ during 4 winters between 2003 and 2011) than before (16 and 4 ind. $\mathrm{m}^{-3}$ in 1989 and 1991, respectively).

The abundances of adult $M$. leidyi and B. ovata varied from year to year (Fig. 3a). Maximum annual abundances ranged over more than 1 order of magnitude for the 2 species, i.e. $M$. leidyi from 26.2 to 254 ind. $\mathrm{m}^{-3}$ in 2003 and 2001, respectively, and $B$. ovata from 6 to 68 ind. $\mathrm{m}^{-3}$ in 2009 and 2001, respectively. The observed succession of peaks (maximum annual values) of $M$. leidyi and B. ovata within each year suggests that the maximum annual abundance of the $B$. ovata predator was related to that of its $M$. leidyi prey. This was indeed the case, as the 2 variables showed a significant positive relationship (Fig. 3b). It must be noted that the very high $M$. leidyi abundance of 254 ind. $\mathrm{m}^{-3}$ was recorded during only one of the surveys, in 2001, when winds exceptionally favoured strong transport toward the coast, as explained in the next section.

Before the arrival of B. ovata, M. leidyi was present in sizable concentrations (i.e. $\geq 5$ ind. $\mathrm{m}^{-3}$ ) from spring through autumn and perhaps also winter (Fig. 2). The succession of the annual periods of growth and decline in the M. leidyi population since 2000 to 2001 indicates that after the arrival of $B$. ovata, the period of the year during which $M$. leidyi was present in sizable concentrations became relatively short (Fig. 3a). Indeed, that period generally lasted less than 2 mo
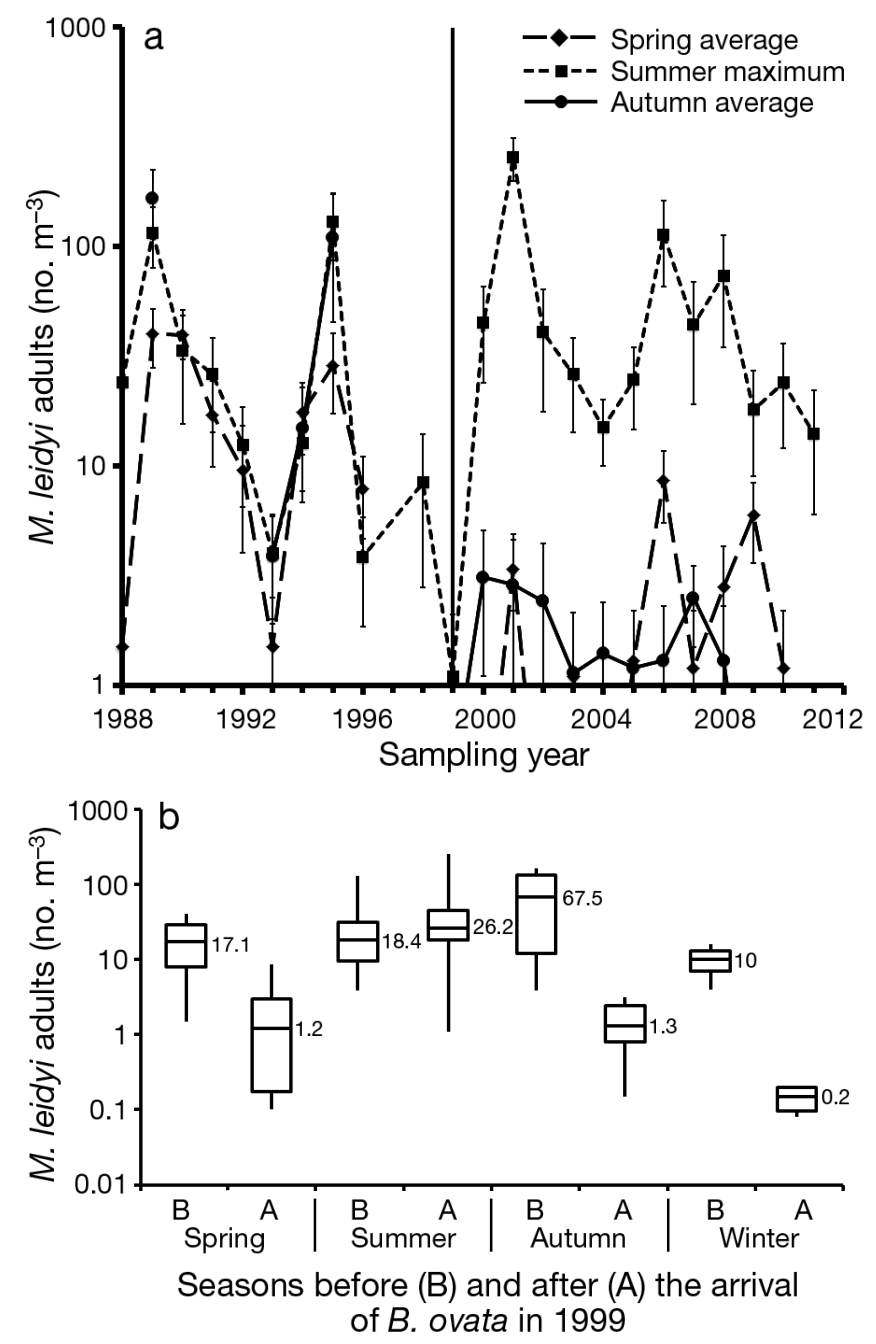

Fig. 2. Abundances of adult Mnemiopsis leidyi at the Blue Bay monitoring station, along the transect and elsewhere in the northeastern Black Sea from 1988 to 2011 during 3 seasons (Table 1, Lines 2 to 5). Spring: average of values from March and April. Summer: annual maximum value before the annual development of the Beroe ovata population. Autumn: average of values from September to November. (a) Lines for summer and autumn averages are superimposed from 1993 to 1995. The vertical line indicates the arrival of B. ovata, the predator of $M$. leidyi, in the area in 1999. Error bars: standard deviations. (b) Boxplot presentation of the same data (vertical line: total range, box: interquartile range, horizontal line: median); value to the right of each box: median

(from late July or August to early or late September) between 2000 and 2007, excluding 2001, when the duration of sizeable abundance lasted 2.4 mo (from middle July to late September) (Fig. 4). During the last $4 \mathrm{yr}$ of the data series (2008 to 2011), M. leidyi started to develop earlier than previously (in May or June), and the duration of its occurrence in sizable concentrations lasted until early or late August 
(Fig. 4). However, the abundances of $M$. leidyi were low during these last 4 yr (Fig. 3a).

\section{Relationships of Mnemiopsis leidyi with temperature, zooplankton and wind}

A springtime temperature (average of March to May) of not less than $11.8^{\circ} \mathrm{C}$ appeared to be necessary for high annual summer abundance of $M$. leidyi to develop (Fig. 5a). We tested this effect by assigning the data to a $2 \times 2$ contingency table that we designed to isolate a cell that contained no observation. This was achieved by using a temperature threshold of $11.8^{\circ} \mathrm{C}$ and a $M$. leidyi threshold of 33 ind. $\mathrm{m}^{-3}$ (Fig. 5a), i.e. the 2 thresholds were not set a priori but resulted from the criterion of isolating a cell of the contingency table that contained no observation. The cells of the contingency table contained the number of observations corresponding to 2 temperatures (i.e. $<11.8$ and $\geq 11.8^{\circ} \mathrm{C}$ ) and 2 maximum annual abundances of $M$. leidyi (i.e. $\leq 33$ and $>33$ ind. $\left.\mathrm{m}^{-3}\right)$. The Wilks' $\chi^{2}$ of the contingency table was 9.77 $(p=0.002$, degree of freedom $=1)$, indicating that in the $23 \mathrm{yr}$ dataset, the maximum abundance of adult $M$. leidyi was not independent from temperature and that it exceeded 33 ind. $\mathrm{m}^{-3}$ only in the $11 \mathrm{yr}$ when the springtime temperature was $\geq 11.8^{\circ} \mathrm{C}$.

The maximum annual abundance of $M$. leidyi was also related to the summer zooplankton biomass, with a significant positive linear relationship between the 2 variables (Fig. 5b). The value of the correlation coefficient (r) did not change after removing the point corresponding to the highest M. leidyi abundance (summer 2001), showing that the value of $r$ was not 'pulled' by that extreme point.

In addition, there was a general visual covariation between the mean concentrations of $M$. leidyi during its month of maximum yearly abundance and the mean velocity of the wind parallel to the coastline

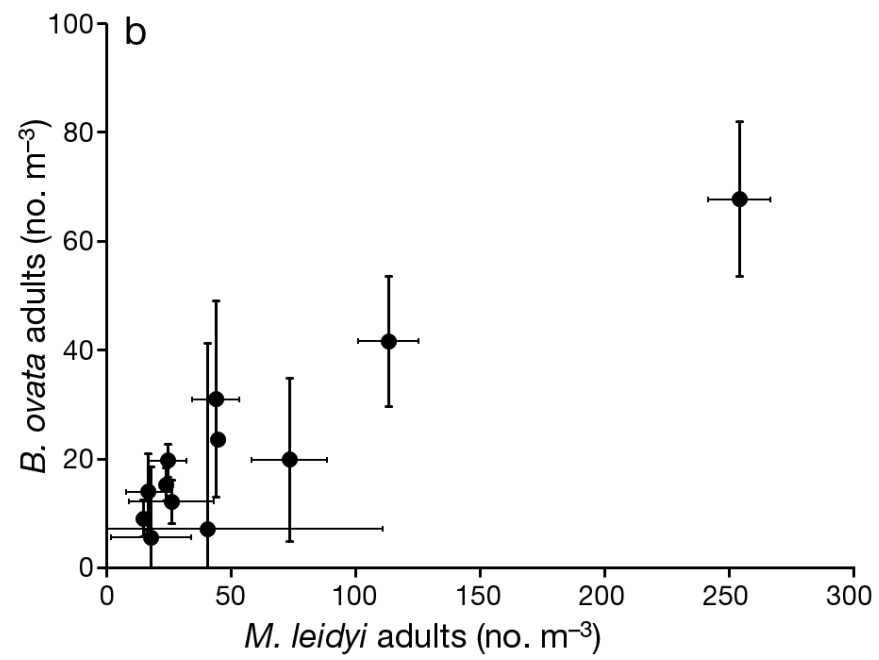

Fig. 3. Abundances of adult Mnemiopsis leidyi and Beroe ovata along the transect in the northeastern Black Sea from 1999 to 2011 (Table 1, Lines 3 and 4). Error bars: standard deviations. (a) Interannual variations of mean values during each sampling survey along the transect in Fig. 1. (b) Maximum annual number of adult $B$. ovata plotted as a function of maximum annual number of adult $M$. leidyi. The coefficient of the linear correlation between the 2 variables is $\mathrm{r}=0.93(\mathrm{p}<0.001, \mathrm{n}=12)$

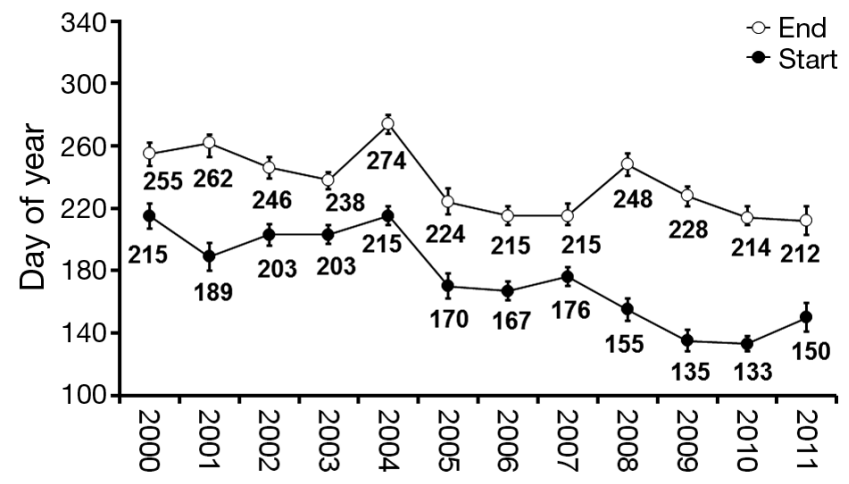

Fig. 4. Periods of the year when Mnemiopsis leidyi abundance was $>5$ ind. $\mathrm{m}^{-3}$, after the arrival of Beroe ovata in the northeastern Black Sea in 1999. Data are from the transect in the northeastern Black Sea in 2000 to 2011 (Table 1, Line 4). Numbers under the lower and upper lines are the mean days of the year when the abundance reached 5 ind. $\mathrm{m}^{-3}$ and fell below that value, respectively. Error bars: standard deviations. Before 1999, M. leidyi was present in concentrations $>5$ ind. $\mathrm{m}^{-3}$ almost year-round (Fig. 2) 

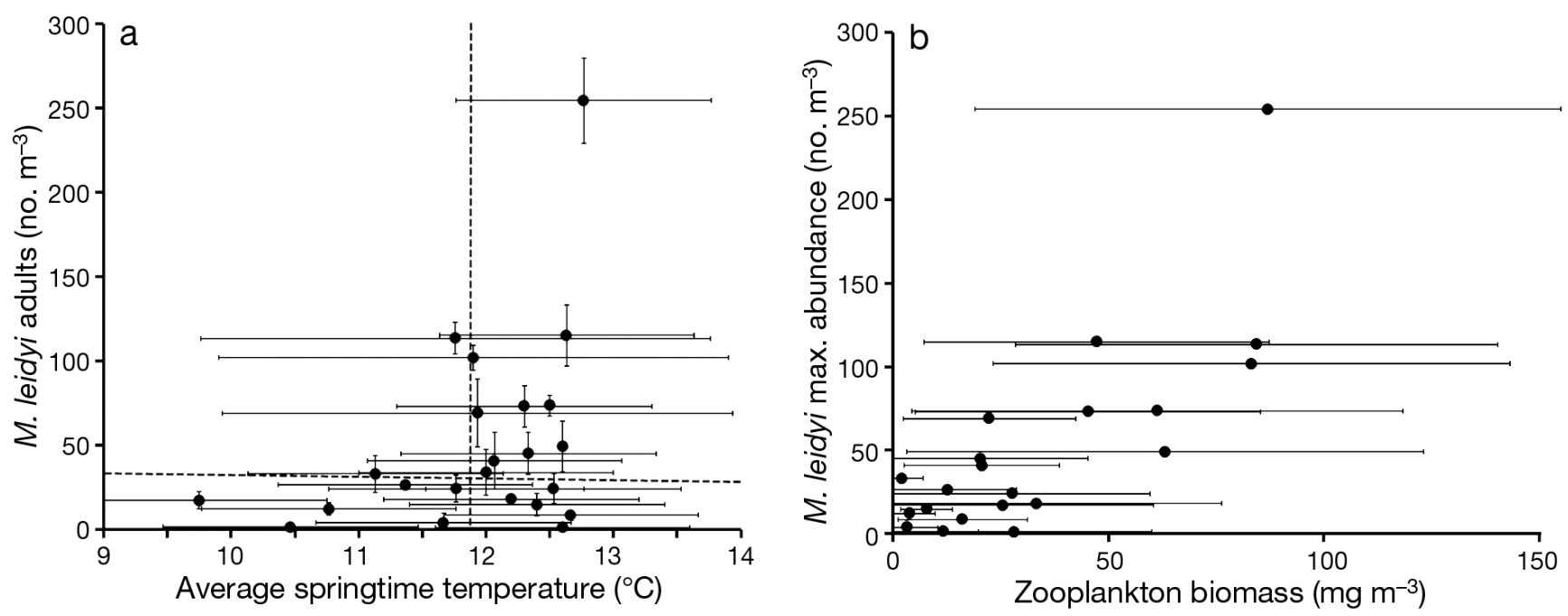

Fig. 5. Maximum annual abundance of adult Mnemiopsis leidyi (i.e. maximum mean annual abundance of adult M. leidyi among all surveys of each year) plotted against 2 environmental variables along the transect in the northeastern Black Sea from 1988 to 2011 (Table 1, Lines 3 and 4, and data for 1988 to 1992 from Vinogradov et al. 1992). Error bars: standard deviations. (a) Springtime temperature: average values from March to May; no springtime data in 1997 ( $\mathrm{n}=23$ ). The vertical dashed line delineates temperatures $<11.8$ and $\geq 11.8^{\circ} \mathrm{C}$, and the horizontal dashed line delineates abundances $\leq 33$ and $>33$ ind. $\mathrm{m}^{-3}$. The corresponding $2 \times 2$ contingency table has Wilks' $\chi^{2}=9.77(\mathrm{p}=0.002$, $\mathrm{df}=1$ ). (b) Summertime zooplankton biomass (wet weight): average values in June and July before the seasonal development of Beroe ovata; no summertime data in 1997 . The coefficient of linear correlation between the 2 variables is $\mathrm{r}=0.79(\mathrm{p}<0.001, \mathrm{n}=21$ or 20 ) with or without inclusion of the point corresponding to the highest $M$. leidyi abundance (2001)

during the same month between 1988 and 2011 (Fig. 6a). Our estimates indicate that wind favouring offshore transport (negative values) generally prevailed during the whole observation period, which is consistent with the seasonal wind climatology over the Black Sea. It means that wind may have affected species concentration through variations in the inten- sity of passive dispersion of organisms (Fig. 6a). The high mean concentrations of $M$. leidyi during its month of maximum yearly abundance generally corresponded to wind velocities close to zero (i.e. weak transport), and the low mean M. leidyi concentrations generally corresponded to strongly negative wind velocities (i.e. strong offshore transport). Strong
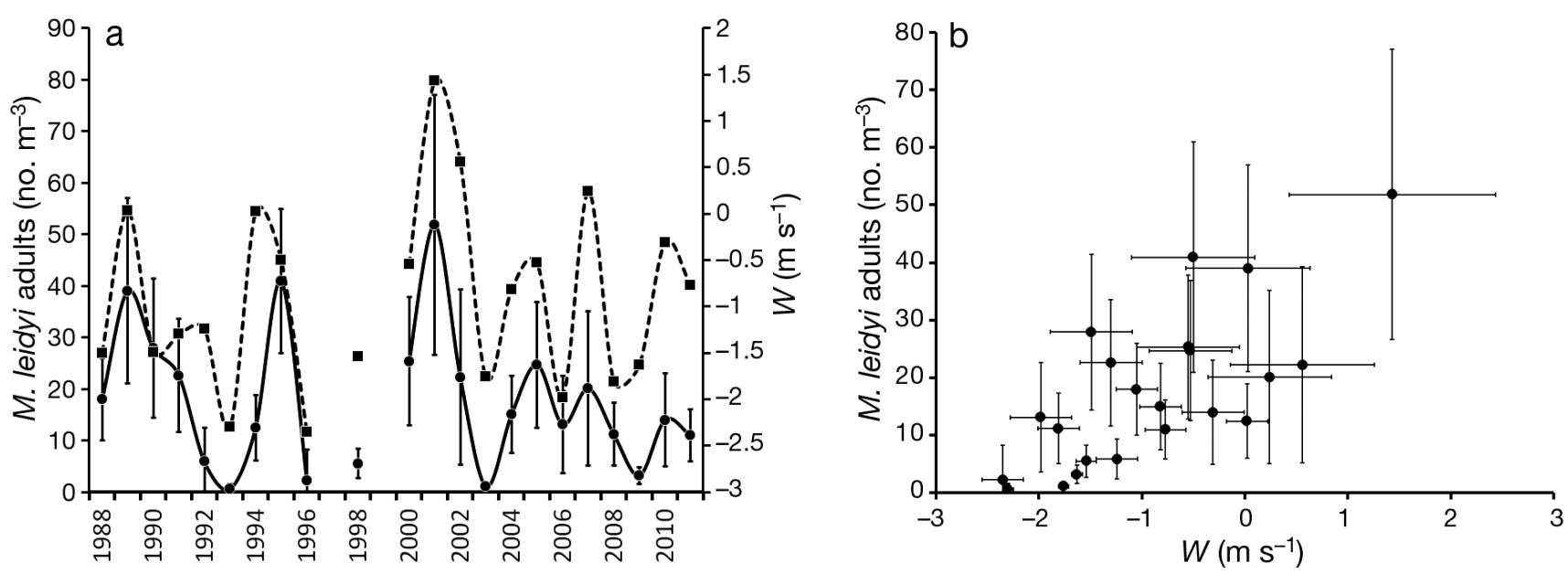

Fig. 6. (a) Mean concentration of adult Mnemiopsis leidyi during the month of its maximum abundance each year (solid line) at the Blue Bay monitoring station and along the transect for all surveys during the month of maximum yearly abundance in the northeastern Black Sea (Table 1, Lines 3 and 4, and data for 1988 to 1992 from Vinogradov et al. 1992), and corresponding mean velocity of the wind parallel to coastline ( $W_{\text {; }}$ dashed line) during the same month in 1988 to 2011 . Time series of the 2 variables. Error bars: standard deviations. (b) $M$. leidyi as a function of wind $(\mathrm{r}=0.73, \mathrm{p}<0.001, \mathrm{n}=22)$. Error bars: standard deviations 
transport toward the coast (strongly positive value of $W$ ) was only observed in 2001 and corresponded to the highest mean $M$. leidyi concentrations during the whole observation period. Using the data for the whole period 1988 to 2011 produced a significant positive linear relationship between the 2 variables (Fig. 6b).

\section{Combined reproductive sequence of Mnemiopsis leidyi and Beroe ovata}

Independent of the above changes in abundances of the 2 species and environmental conditions over the data series (Figs. $5 \& 6$ ), the same combined reproductive sequence of $M$. leidyi and $B$. ovata took place every year. The reproductive sequence comprised 7 steps (Fig. 7): (1) adult $M$. leidyi started to reproduce, (2) reproduction of $M$. leidyi reached its annual peak value, (3) adult $B$. ovata appeared in the sampling area, (4) adult B. ovata started to reproduce, (5) reproduction of $B$. ovata reached its annual peak value, (6) M. leidyi larvae disappeared from the sampling area, and (7) B. ovata larvae disappeared from the sampling area (in a few years, Step 7 occurred slightly before Step 6). The interweaving of

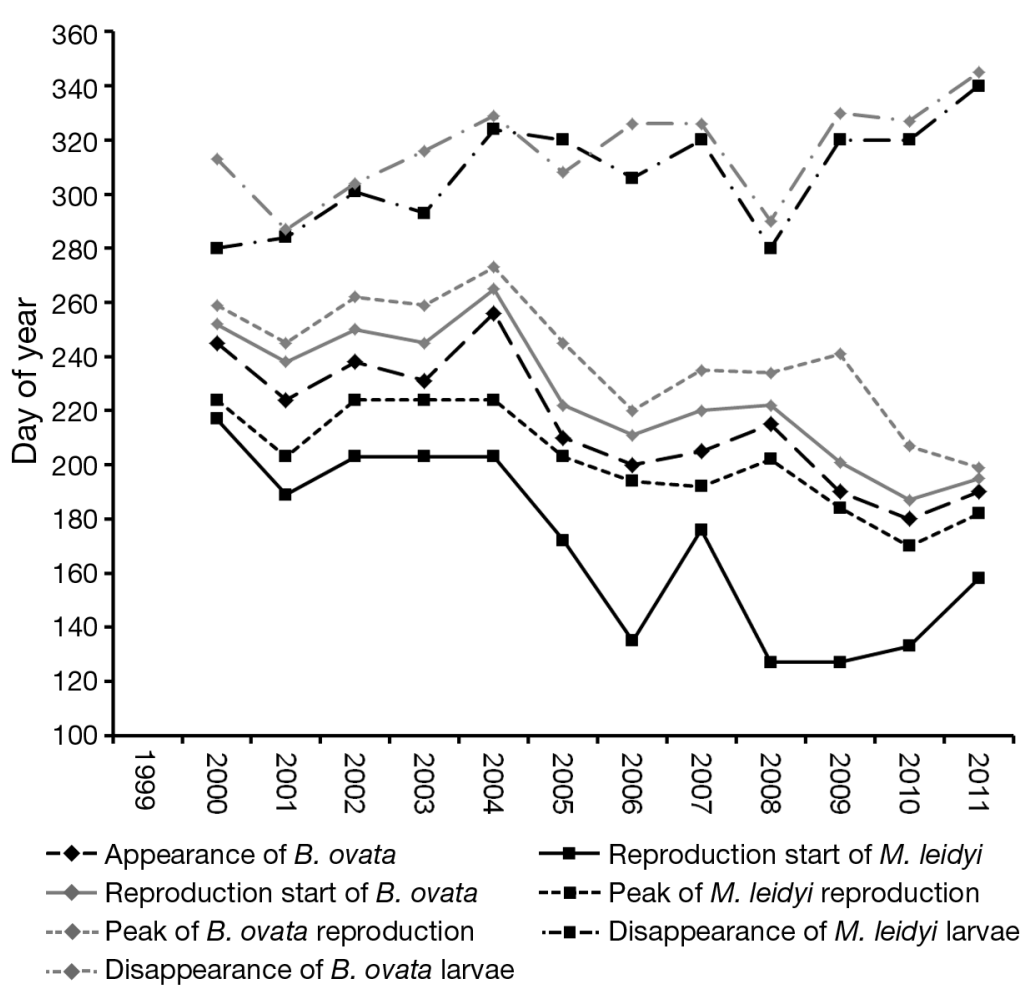

Fig. 7. Combined reproductive sequence of Mnemiopsis leidyi and Beroe ovata at the Blue Bay daily monitoring station (Fig. 1) from 2000 to 2011 (Table 1, Line 2) the reproductive sequences of the 2 species indicates that the time scales of the 2 sequences were consistent, which allowed the strong interaction between the prey and its predator.

The above sequence repeated itself every year from 2000 until 2011, although with some temporal variations (Fig. 7). For example, the first yearly observation of adult $B$. ovata in the sampling area, shortly after $M$. leidyi reached its annual reproduction peak, was on 13, 26, 10, 22 and 15 August in 1999 through 2003, respectively (the data point for 1999 is not shown in Fig. 7 because of an incomplete set of observations that year); 12 September in 2004; 27 June in 2005; and in July every year after 2005. Also, in 2005 and contrary to the other years, the larvae of $B$. ovata disappeared from samples slightly before those of $M$. leidyi.

From 2005 on, M. leidyi seemed to develop in significant numbers (i.e. $>5$ ind. $\mathrm{m}^{-3}$ ) earlier than before (Fig. 4). It also seemed to start reproducing and to reach peak reproduction earlier than before, i.e. reproduction started earlier than Day 180 in 2005 to 2011 versus later than Day 180 in 2000 to 2004 (Fig. 7). To test if this visual difference was statistically significant, we used a Mann-Whitney $U$-test to verify if reproduction of $M$. leidyi really started earlier in 2005 to 2011 (Period A) than in 2000 to 2004 (Period B) and found a significant difference $(U=42.0,1$-tailed $\mathrm{p}=$ $0.001, \mathrm{n}_{\mathrm{B}}=6, \mathrm{n}_{\mathrm{A}}=7$ ). In addition, the starting date of reproduction of $M$. leidyi between 1992 and 2011 was significantly and inversely related to the average temperature in the surface layer in June, i.e. the reproduction of $M$. leidyi started earlier in warmer years, and the highest June temperatures $\left(>22^{\circ} \mathrm{C}\right)$ all occurred between 2006 and 2011 (Fig. 8).

\section{DISCUSSION}

\section{Black Sea zooplankton before and after the arrival of ctenophores}

Before the arrival of Mnemiopsis leidyi in the Black Sea, the biomasses of edible zooplankton (i.e. without Noctiluca scintillans, which is not edible) could reach annual mean values of $48 \mathrm{mg} \mathrm{m}^{-3}$ wet weight in Blue Bay and higher in other areas (79 $\mathrm{mg} \mathrm{m}^{-3}$ wet weight in Gelendzhik Bay in 1978) (Pasternak 1983). The 


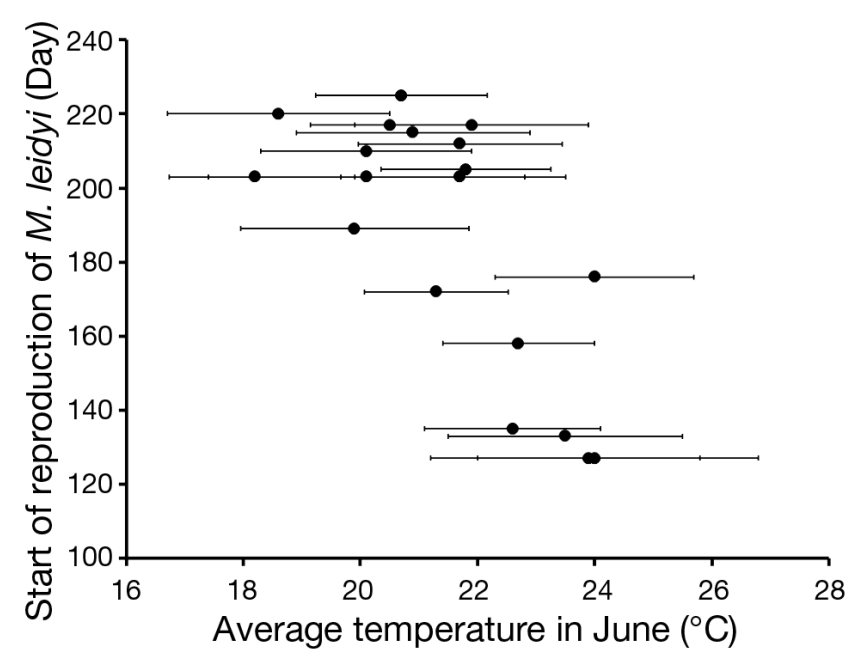

Fig. 8. Starting day of the year of reproduction of adult Mnemiopsis leidyi plotted as a function of average temperature in the surface layer in June at the Blue Bay monitoring station and along the transect from 1992 to 2011 (Table 1, Lines 1 to 5). All temperatures $>22^{\circ} \mathrm{C}$ occurred between 2006 and 2011. The coefficient of linear correlation between the 2 variables is $r=-0.78(p<0.001, n=19)$. Error bars: standard deviations for average temperature in June

abundance and biomass of zooplankton showed 2 seasonal peaks in a year. The first peak occurred in spring in association with the spring phytoplankton bloom, if any. The reproduction of cold-water and eurythermal copepod species (i.e. Pseudocalanus elongatus, Calanus euxinus, Oithona similis and Paracalanus parvus) and the appearance of their ovae, nauplii and copepodites caused the initial increase in zooplankton. Later in spring, zooplankton developed high biomasses, which consisted mostly of the above-mentioned species and reproduction of more eurythermal organisms such as Acartia clausi and Oikopleura dioica as well as warm-water species such as the cladoceran Pleopis polyphemoides. The second zooplankton peak occurred in AugustSeptember, corresponding to the development of warm-water surface species (Penilia avirostris, other cladocerans, and the copepod Centopages ponticus), the continued development of eurythermal copepods (P. parvus, A. clausi, Oithona nana, and O. similis) and of meroplanktonic larvae of benthic species. Before the arrival of $M$. leidyi in the Black Sea, the second zooplankton peak was often higher than the first, particularly in the coastal waters (Pasternak 1983, Kovalev et al. 1993).

After the arrival of $M$. leidyi in the Black Sea in 1982 and the development of its populations around the whole basin in 1988, the maximum annual zooplankton biomasses went down to $1.2-2.3 \mathrm{mg} \mathrm{m}^{-3}$ wet weight (Fig. 5b) during 1991 to 1992, i.e. more than 1 order of magnitude lower than previously (Khoroshilov \& Lukasheva 1999). This dramatic difference is one of the major environmental effects that followed the invasion of the Black Sea by M. leidyi (see 'Introduction'). Simultaneously, the biodiversity of mesozooplankton species decreased drastically, from 20-60 species depending on the season and area down to 4-6 species. Some copepods belonging to Pontellidae as well as $C$. ponticus and $O$. nana and the chaetognath Parasagitta setosa almost completely disappeared during the years that followed the $M$. leidyi invasion. Although mesozooplankton diversity mostly recovered after Beroe ovata arrival, $O$. nana disappeared completely from the Black Sea (Shiganova et al. 2004). These negative ecosystemlevel effects and their later attenuation can be understood through the assessment of the 3 hypotheses stated at the end of the 'Introduction'.

\section{Assessment of the first hypothesis}

The first hypothesis examined in this paper is that every year since the arrival of B. ovata (in 1999 in the northeastern Black Sea, discussed here), its population dynamics have controlled the period of the year during which $M$. leidyi was present in sizable concentrations. This is supported by field evidence, i.e. before the arrival of $B$. ovata, the abundance of $M$. leidyi was generally $>5$ ind. $\mathrm{m}^{-3}$ almost year-round (Fig. 2), whereas after the arrival of B. ovata, the occurrence of $M$. leidyi at $>5$ ind. $\mathrm{m}^{-3}$ was generally restricted to 2 or 3 summer months depending on the starting time of $B$. ovata seasonal development (Fig. 4). Results of Mann-Whitney $U$-tests on data in Fig. 2 are consistent with the hypothesis that the occurrence of $M$. leidyi in sizable concentrations had been restricted to the summer months since the arrival of $B$. ovata.

Because the only known prey of predator B. ovata in the investigated area is $M$. leidyi, the annual abundance of the predator tracked that of its prey over the years that followed the predator's arrival in the Black Sea (Fig. 3). This shows the effect of the prey's abundance on that of its predator. Conversely, the predator affected the abundance of its prey through the mechanism of predation (Fig. 2), which is activated yearly by the arrival of $B$. ovata in the water column where the M. leidyi population is developing (Fig. 7). The predator starts feeding on its only prey and reproduces until it exhausts the prey population, after which its own population declines, and the 
remaining individuals of the new generation take refuge elsewhere (e.g. in the bottom layer) until next year's development of the prey population (Shiganova et al. 2003, 2004). The tight connection between the dynamics of $M$. leidyi and B. ovata was possible because the time scales of their 2 reproductive sequences were consistent (Fig. 7).

The fact that the period of the year during which $M$. leidyi was present was much shorter in the decade after the arrival of $B$. ovata than in the decade before indicates that $B$. ovata shortened the duration of high M. leidyi populations down to 2-3 summer months (Fig. 4) every year after its arrival. The mechanism of this control was described in the previous paragraph, and its effect on $M$. leidyi, is evidenced by Figs. $2 \& 7$ and by the above statistical analyses of the relevant data. Similarly, the unusual appearance of beroid-predatory B. ovata in Narragansett Bay (northeastern USA) in 2006 coincided with a rapid disappearance of $M$. leidyi there (Beaulieu et al. 2013). A mechanism similar to that described here has been observed for the ctenophore prey Pleurobrachia pileus and its predator, B. gracilis, in the North Sea, where B. gracilis appeared in the water column within $5 \mathrm{~d}$ of the development of the population of P. pileus (Greve 1976).

\section{Assessment of the second hypothesis}

The second hypothesis examined here is that because $B$. ovata and $M$. leidyi continued to coexist every year in the northeastern Black Sea after 1999, the same annual sequence of predator-prey mechanisms led $B$. ovata to shorten the duration of sizable $M$. leidyi populations relative to the situation before the arrival of the predator, irrespective of the interannual environmental variability. This is supported by the field repetition, every year since 1999, of the same combined reproductive sequence for $M$. leidyi and B. ovata (Fig. 7). This sequence comprised the 7 steps described in the 'Results'.

Some larvae of 2 species are still found at sea several months after the abundance maxima of adults (e.g. >100 d in 2011, Fig. 7). This phenomenon suggests that the few surviving adults continue to reproduce but that further development of larvae fails. The 2 species are assumed to survive during winter at low abundances without reproducing but with a low mortality rate if the temperature is not too low ( $\mathrm{T}$. Shiganova pers. obs.). In Narragansett Bay, shallow embayments serve as winter refuges for M. leidyi, from where grown adults spread into the open bay waters starting in spring (Costello et al. 2006). Similarly, survival of polyps in winter was reported by Prieto et al. (2010) for Cotylorhiza tuberculata (Macri, 1778), a scyphozoan jellyfish that generates large outbreaks in the Mediterranean Sea. Contrary to these situations, M. leidyi cannot use Blue Bay as a winter refuge because this water body is open to the Black Sea.

The duration of the reproductive sequence varied from year to year; it ranged between $73 \mathrm{~d}$ in 1999 and $203 \mathrm{~d}$ in 2009, but the sequence itself (i.e. the order of events) remained unchanged over the $13 \mathrm{yr}$ period, with few exceptions. Repetition of the same 7 step sequence over $13 \mathrm{yr}$ is a remarkable characteristic of the B. ovata-M. leidyi predator-prey relationship in the Black Sea, especially because it was independent of the maximum numbers reached by the 2 species in different years (Fig. 3a) or the interannual changes in surface water temperature (Fig. 5a) or food concentration (Fig. 5b), which are examined below in relation to the third hypothesis. The mechanism responsible for the shorter duration of sizable $M$. leidyi populations to 2 or 3 spring-summer months since the arrival of B. ovata in the northeastern Black Sea was examined above when discussing the first hypothesis. This mechanism is the development of predatory populations of $B$. ovata in response to the seasonal development of $M$. leidyi populations. The yearly repetition of the robust reproductive sequence of $M$. leidyi and B. ovata observed at sea during $13 \mathrm{yr}$, independent of variations in environmental conditions, is consistent with our hypothesis that it is through the same annual sequence of predator-prey mechanisms that $B$. ovata shortened the duration of sizable M. leidyi populations to 2 or 3 spring-summer months.

\section{Assessment of the third hypothesis}

The third hypothesis examined here is that because there were strong interannual variations in the abundances of both M. leidyi and B. ovata, environmental conditions determined the joint abundances of the 2 species. There was strong covariability between the numbers of M. leidyi and B. ovata every year after the arrival of the latter in the northeastern Black Sea in 1999 (Fig. 3a), with a significant positive relationship between the yearly maximum numbers of the 2 species during the period 2000 to 2011 (Fig. 3b). Hence, environmental variables affected the 2 species through their effects on the prey, M. lei$d y i$, which in turn affected the predator, B. ovata. 
Consequently, the third hypothesis is assessed here by examining relationships between environmental factors and the abundances of $M$. leidyi.

In our 23 yr dataset, the maximum abundance of $M$. leidyi was significantly related to springtime temperature, i.e. the value of 33 ind. $\mathrm{m}^{-3}$ was exceeded only in the $11 \mathrm{yr}$ when springtime temperature was $\geq 11.8^{\circ} \mathrm{C}$ (Fig. 5a). The critical value of $11.8^{\circ} \mathrm{C}$ in the Black Sea was close to the minimum temperature required for the occurrence of substantial egg production ( $>10$ eggs ind. ${ }^{-1} \mathrm{~d}^{-1}$ ) in Narragansett Bay (Costello et al. 2006). Our result was also consistent with the field-based observation of Shiganova et al. (2001b) that high spring temperatures elicited intense onset of reproduction and rapid population growth of $M$. leidyi. In addition, the onset of reproduction of $M$. leidyi was significantly and inversely related to the early summer temperature (i.e. June; Fig. 8), which was higher after 2005 than before $\left(>22^{\circ} \mathrm{C}\right.$ from 2006 onwards). Hence, higher early summer temperature may have stimulated the earlier start of reproduction of M. leidyi after 2005 than in the period before this (Fig. 7). Furthermore, the maximum annual abundance of $M$. leidyi was positively related to the summer biomass of its zooplankton food (i.e. average concentration in June and July, before the annual appearance of B. ovata; Fig. 5b). This may imply that higher temperatures in spring are a necessary but not sufficient condition for having a high abundance of $M$. leidyi and that the latter requires both higher spring temperatures and high summer food, i.e. high zooplankton biomass.

The above field results are consistent with conclusions from previous observations and laboratory experiments. For example, Shiganova et al. (2001b) assumed that the interannual variability in M. leidyi was especially linked with changes in surface water temperature and food concentration, i.e. edible micro- and mesozooplankton. Similarly, Costello et al. (2006) concluded that among-year variation in spring warming was a major factor in regulating the onset of reproduction. Likewise, Kremer (1994) suggested that, based on laboratory experiments on $M$. leidyi from native waters, temperature was the most important factor in the development of $M$. leidyi and food came second. Shiganova et al. (2004) came to a similar conclusion based on laboratory experiments on M. leidyi from Black Sea waters.

In addition, there was a general covariation between the mean concentration of $M$. leidyi during the month of its maximum yearly abundance and the mean wind velocity parallel to the coast during the same month over the 23 yr dataset (Fig. 6a) and a positive linear correlation between the 2 variables during the same period (Fig. 6b). These relationships suggest wind-driven transport of $M$. leidyi (and its predator, B. ovata, when present) toward the coast (i.e. passive accumulation of organisms, a rare situation given the seasonal wind climatology over the Black Sea) or offshore (i.e. passive dispersion of organisms). Extremely low mean $M$. leidyi concentration during its month of maximum abundance was observed during the strong wind-driven transport offshore in 1993 and 2003.

The extreme situation of the highest mean M. leidyi concentration during its month of maximum abundance in 2001 associated with strong wind-driven transport toward the coast (Fig. 6a) set the overall study in the more general context of climate variability. Indeed, the differences in the wind regime may be associated with the variability of large-scale atmospheric forcing, e.g. the North Atlantic Oscillation (NAO). The winter mean NAO index was strongly negative $(-0.5)$ in 2001. In a previous study, Kazmin \& Zatsepin (2007) showed that in a positive NAO index situation (NAO $>0$ ), which is generally more frequent than a negative index, the southern-western wind regime (i.e. favourable for offshore transport) prevailed over the whole Black Sea basin, and in a negative index situation (NAO <0), the wind regime switched to the northeast (i.e. favourable to flow toward the shore). Part of the variability observed in the $23 \mathrm{yr} M$. leidyi series in the inshore waters of the northeastern Black Sea could therefore reflect an effect of NAO over the whole basin.

\section{Propagation of changes from the environment to Mnemiopsis leidyi and to Beroe ovata}

An important concluding point is the propagation of changes in the abundance of $M$. leidyi to changes in the abundance of B. ovata. For example, the earlier reproduction of $M$. leidyi after 2005, which as described above was attributed to the higher early summer temperature (i.e. in June), was accompanied by an earlier appearance and reproduction of $B$. ovata (Fig. 7). This is a consequence of the predator-prey relationship between $B$. ovata and $M$. leidyi, i.e. the predation of the first on the second. Because of this relationship, environmental changes that affect the population dynamics of $M$. leidyi propagate from interannual changes in the abundance of that prey species to proportional (although nonlinear) changes in the abundance of its predator, B. ovata. 


\section{CONCLUSION}

The results of our study showed the predator-prey interactions of Mnemiopsis leidyi and Beroe ovata in the Black Sea. Each year, the development of the prey, $M$. leidyi, was followed by the development of the predator, $B$. ovata, within a very short time period. The annual development and abundance of the prey and, consequently, of its predator were determined by environmental conditions. Those identified in this study were surface water temperature in spring and early summer, concentration of M. leidyi food (i.e. zooplankton biomass) in summer at the time of the annual development of that species, and velocity of wind favourable to transport normal to the coast during the month of maximum $M$. leidyi abundance. However, other environmental factors may also influence the joint abundances of $M$. leidyi and B. ovata in the natural environment.

Understanding the mechanisms of interactions between $M$. leidyi and B. ovata, and especially the control of the M. leidyi population size by B. ovata, has become crucial because $M$. leidyi is spreading around the world ocean, and B. ovata is following it in some cases (Shiganova et al. 2004, 2007, Shiganova \& Malej 2009, Galil et al. 2011). In other cases, native species belonging to the genus Beroe (other than B. ovata) are preying on the invading $M$. leidyi (Shiganova \& Malej 2009).

Acknowledgements. This paper was written with financial support from the cooperation agreement between the Russian Academy of Sciences and the French CNRS and from EU projects PERSEUS and COCONET. We thank reviewers and Dr. Martin Lilley (Villefranche-sur-Mer) for their useful comments and suggestions.

\section{LITERATURE CITED}

Bayha KM, Harbison GR, Mcdonald JH, Gaffney PM (2004) Preliminary investigation on the molecular systematics of the invasive ctenophore Beroe ovata. In: Dumont $\mathrm{H}$, Shiganova T, Niermann U (eds) The ctenophore Mnemiopsis leidyi in the Black, Caspian and Mediterranean Seas and other aquatic invasions. NATO ASI Series 4, Kluwer Academic Publishers, Dordrecht, p 167-175

Beaulieu WT, Costello JH, Klein-Macphee G, Sullivan BK (2013) Seasonality of the ctenophore Mnemiopsis leidyi in Narragansett Bay, Rhode Island. J Plankton Res 35: 785-791

Boero F, Putti M, Trainito E, Prontera E, Piraino S, Shiganova $\mathrm{T}$ (2009) Recent changes in western Mediterranean Sea biodiversity: the establishment of Mnemiopsis leidyi (Ctenophora) and the arrival of Phyllorhiza punctata (Cnidaria). Aquat Invasions 4:675-680

Caddy JF, Griffiths RC (1990) A perspective on recent fish- ery-related events in the Black Sea. GFCM Stud Rev 63: 43-71

Cociasu A, Lazar L, Vasiliu D (2008) New tendency in nutrient evolution from Romanian coastal waters. Cercet Mar $38: 7-23$

Costello JH, Sullivan BK, Gifford DJ, Van Keuren D, Sullivan LJ (2006) Seasonal refugia, shoreward thermal amplification, and metapopulation dynamics of the ctenophore Mnemiopsis leidyi in Narragansett Bay, Rhode Island. Limnol Oceanogr 51:1819-1831

Costello JH, Bayha KM, Mianzan HW, Shiganova TA, Purcell JE (2012) The ctenophore Mnemiopsis leidyi: transitions from a native to an exotic species. Hydrobiologia 690: 21-46

- Daskalov GM, Grishin AN, Rodianov S, Mihneva V (2007) Trophic cascades triggered by overfishing reveal possible mechanisms of ecosystem regime shifts. Proc Natl Acad Sci USA 104:10518-10523

Faasse MA, Bayha KM (2006) The ctenophore Mnemiopsis leidyi A. Agassiz 1865 in coastal waters of the Netherlands: an unrecognized invasion? Aquat Invasions 1:270-277

Finenko GA, Romanova ZA, Abolmasova GI, Anninsky BE and others (2003) Population dynamics, ingestion, growth and reproduction rates of the invader Beroe ovata and its impact on plankton community in Sevastopol Bay, the Black Sea. J Plankton Res 25:539-549

Fuentes VL, Angel DL, Bayha KM, Atienza D and others (2010) Blooms of the invasive ctenophore Mnemiopsis leidyi span the Mediterranean Sea in 2009. Hydrobiologia 645:23-37

Galil BS, Kress N, Shiganova TA (2009) First record of Mnemiopsis leidyi A. Agassiz, 1865 (Ctenophora Lobata Mnemiidae) off the Mediterranean coast of Israel. Aquat Invasions 4:356-362

Galil BS, Gevili R, Shiganova T (2011) Not far behind: first record of Beroe ovata Mayer, 1912 (Ctenophora: Beroida: Beroidae) off the Mediterranean coast of Israel. Aquat Invasions 6:S89-S90

Ghabooli S, Shiganova TA, Zhan A, Cristescu M, EghtesadiAraghi P, MacIsaac H (2011) Multiple introductions and invasion pathways for the invasive ctenophore Mnemiopsis leidyi in Eurasia. Biol Invasions 13:679-690

Gill AE (1982) Atmosphere-ocean dynamics. Academic Press, New York, NY

> Greve W (1976) Die Rippenquallen der südlichen Nordsee und ihre interspezifischen Relationen. Publik Wiss Film Göttingen 9(1):53-62

Ivanov L, Beverton RJH (1985) The fisheries resources of the Mediterranean. Part 2: Black Sea. GFCM Stud Rev 60

Javidpour J, Sommer U, Shiganova T (2006) First record of Mnemiopsis leidyi A. Agassiz, 1865 in the Baltic Sea. Aquat Invasions 1:299-302

Kazmin AS, Zatsepin AG (2007) Long-term variability of surface temperature in the Black Sea, and its connection with the large-scale atmospheric forcing. J Mar Syst 68: 293-301.

Khoroshilov VS, Lukasheva TA (1999) Changes of zooplankton community of the Blue Bay after introduction of Mnemiopsis in the Black Sea. Oceanology (Mosc) 39:1-6

Konsulov A, Kamburska L (1998) Ecological determination of the new ctenophore (Beroe ovata) invasion in the Black Sea. Inst Oceanol 2:195-197

Kovalev AV Melnikov VV, Ostrovskaya NA, Prusova IY (1993) Mesoplankton. In: Kovaler AV (ed) Black Sea plankton. Naukova Dumka, Kiev, p 183-204 (in Russian) 
Kremer P (1994) Pattern of abundance for Mnemiopsis in US coastal waters: a comparative overview. ICES J Mar Sci 51:347-354

Llope M, Daskalov GM, Rouyer TA, Mihneva V, Chan KS, Grishin AN, Stenseth NC (2011) Overfishing of top predators eroded the resilience of the Black Sea system regardless of the climate and anthropogenic conditions. Glob Change Biol 17:1251-1265

Oguz T, Cokacar T (2003) Climatic warming and accompanying changes in the ecological regime of the Black Sea during 1990s. Global Biogeochem Cycles 17:1088, doi: 10.1029/2003GB002031

Oguz T, Velikova V (2010) Abrupt transition of the northwestern Black Sea shelf ecosystem from a eutrophic to an alternative pristine state. Mar Ecol Prog Ser 405:231-242

Oguz T, Fach B, Salihoglu B (2008) Invasion dynamics of the alien ctenophore Mnemiopsis leidyi and its impact on anchovy collapse in the Black Sea. J Plankton Res 30: 1385-1397

Pasternak AF (1983) Seasonal dynamics of abundance and biomass of zooplankton in the inshore waters of the north Caucasus. In: Sorokin YI, Vedernikov VI (eds) Seasonal variability of the Black Sea plankton. Nauka, Moscow, p 139-177 (in Russian)

Petranu A (1997). Black Sea biological diversity. Romania. United Nations Publication, New York, NY

Prieto L, Astorga D, Navarro G, Ruiz J (2010) Environmental control of phase transition and polyp survival. PLoS ONE 5:e13793

Reusch TBH, Bolte S, Sparwell M, Moss AG, Javidpour J (2010) Microsatellites reveal origin and genetic diversity of Eurasian invasions by one of the world's most notorious marine invader, Mnemiopsis leidyi (Ctenophora). Mol Ecol 19:2690-2699

Seravin LN, Shiganova TA, Luppova NE (2002) History of studying the ctenophore Beroe ovata (Ctenophora, Atentaculata, Beroida) and some structural features of its representative from the Black Sea. Zool Zhurnal 81:1193-1201 (in Russian)

Shiganova TA (1998) Invasion of the Black Sea by the ctenophore Mnemiopsis leidyi and recent changes in pelagic community structure. Fish Oceanogr 7:305-310

Editorial responsibility: Alejandro Gallego,

Aberdeen, UK
Shiganova TA, Christou ED, Siokou-Frangou I (2007) First finding of alien species Beroe ovata Mayer 1912 in the Aegean Sea. Mediterr Mar Sci 8:5-14

Shiganova T, Malej A (2009) Native and non-native ctenophores in the Gulf of Trieste, northern Adriatic Sea. J Plankton Res 31:61-71

Shiganova TA, Bulgakova YV, Volovik SP, Mirzoyan ZA, Dudkin SI (2001a) A new invader Beroe ovata Mayer 1912 and its effect on the ecosystems of the Black and Azov Seas. Hydrobiologia 451:187-197

Shiganova T, Mirzoyan Z, Studenikina E, Volovik S and others (2001b) Population development of the invader ctenophore Mnemiopsis leidyi in the Black Sea and other seas of the Mediterranean basin. Mar Biol 139:431-445

Shiganova TA, Musaeva EI, Bulgakova YV and others (2003) Invaders ctenophores Mnemiopsis leidyi (A. Agassiz) and Beroe ovata Mayer 1912, and their influence on the pelagic ecosystem of northeastern Black Sea. Biol Bull Russ Acad Sci 30:180-190

Shiganova TA, Dumont HJD, Mikaelyan A, Glazov D and others (2004) Interaction between the invading ctenophores Mnemiopsis leidyi (A. Agassiz) and Beroe ovata Mayer 1912, and their influence on the pelagic ecosystem of the northeastern Black Sea. In: Dumont H, Shiganova T, Niermann U (eds) The ctenophore Mnemiopsis leidyi in the Black, Caspian and Mediterranean seas and other aquatic invasions. NATO ASI Series 2, Environment, Kluwer Academic Publishers, Dordrecht, p 33-70

Vinogradov ME, Shushkina EA, Musaeva EI, Sorokin PY (1989) Ctenophore Mnemiopsis leidyi (A. Agassiz) (Ctenophora: Lobata) - new settlers in the Black Sea. Oceanology (Mosc) 29:293-298

Vinogradov ME, Sapozhnikov VV, Shushkina EA (1992) The Black Sea ecosystem. Nauka, Moscow (in Russian)

Zaitsev YP, Alexandrov BG (eds) (1998) Black Sea biological diversity, Ukraine. United Nations Publication, New York, NY

Zatsepin AG, Kremenetsky VV, Stanichnyi SV, Burdyugov VM (2010) Basin-scale circulation and mesoscale dynamics of the Black Sea under wind effect. In: Frolov AV, Resnyansky YD (eds) Current state of ocean and atmosphere dynamics. Triada, Moscow, p 347-368 (in Russian)

Submitted: November 18, 2013; Accepted: April 4, 2014 Proofs received from author(s): June 24, 2014 